\title{
PANDANGAN ISLAM DAN PENGARUH KURS, BI RATE TERHADAP INFLASI
}

\author{
Fadilla \\ Prodi Perbankan Syariah STEBIS IGM Palembang \\ Email : haninfadilla423@gmail.com \\ Havis Aravik \\ Prodi Perbankan Syariah STEBIS IGM Palembang \\ Email : havisaravik@gmail.com
}

\begin{abstract}
ABSTRAK
Inflasi merupakan masalah utama dalam perekonomian suatu negara terutama negara berkembang termasuk di Indonesia. Penelitian ini bertujuan untuk menguji pengaruh BI rate dan nilai tukar (kurs) terhadap inflasi yang terjadi di Indonesia sepanjang tahun 2012-2017. Pengujian dalam penelitian ini menggunakan analisis regresi linier berganda. Hasil penelitian ini membuktikan bahwa BI rate dan kurs berpengaruh bersama-sama mempengaruhi inflasi. Namun pengujian parsial membuktikan bahwa hanya BI rate yang berpengaruh terhadap inflasi sedangkan nilai tukar (kurs) tidak berpengaruh terhadap inflasi.
\end{abstract}

Key word : Inflasi, BI rate dan kurs

\section{Latar Belakang}

Sebuah negara tidak dapat hidup sendiri, dia membutuhkan negara lain untuk dapat memenuhi kebutuhan masyartakatnya. Kebutuhan ini bersifat materil maupun non-materil. Kebutuhan non materil ini seperti pengetahuan, kesehatan, dan lain sebagainya. Dalam bidang pengetahuan ini dapat terlihat dari banyaknya Universitas Indonesia yang bekerja sama dengan universitas di luar negeri baik universitas swasta ataupun universitas negeri. Podomoro Universiti bekerja sama dengan Boston University di Jerman. Indonesia juga salah anggota badan kesahatan dunia WHO (Wealth health Organization). Adapun kebutuhan materil merupakan kebutuhan dalam bidang ekonomi dan salah satu kerja sama yang tidak mungkin dihindari adalah kerja sama dalam bidang ekonomi.

Negara Indonesia termasuk negara yang masih melakukan hubungan kerja sama dalam bidang ekonomi baik bilateral, regional dan internasional. Salah satu fakta yang mencenangkan adalah Indonesia masih mengimpor beras. Meskipun pemerintah mengklaim swasembada beras. Kenyataannya harga beras Indonesia yang jauh lebih tinggi dibandingkan harga global, menjadi salah satu penyebab terjadi loncakan harga beras yang berujung pada inflasi (Tia Dwitiani Komalasari, 2017)

Pengamat Ekonomi Pertanian, Bustanul Arifin mengatakan, impor beras era pemerintahan Jokowi mencapai 2,74 juta ton dengan nilai $\mathrm{Rp} 15,7$ triliun berdasarkan data Pemberitahuan Impor Barang Ditjen Bea Cukai. Impor tersebut sebanyak 503 ribu ton pada akhir 2014, 861 ribu ton pada $2015,1,2$ juta ton pada 2016, dan 94 ribu ton pada Januari-Mei 2017.(Tia Dwitiani Komalasari, 2017). Kejadian ini membuktikan bahwa untuk memenuhi kebutuhan pokok saja pemerintah masih membutuhkan negara lain.

Kerja sama dalam bidang ekonomi tidak hanya dilakukan dalam jual-beli, Indonesia juga ikut dalam perkumpulan masyarakat Ekonomi. Masyarakat Ekonomi ASEAN (MEA) atau ASEAN Economic Community (AEC) dibentuk oleh negara-negara yang terdapat di Asia 
Tenggara. Indonesia dan sembilan anggota ASEAN lainnya memasuki persaingan yang sangat ketat di bidang ekonomi.

Pada dasarnya, MEA merupakan wadah penting bagi kemajuan negaranegara ASEAN dalam mewujudkan kesejahteraan sehingga keberadaannya harus disikapi dengan positif. Dan diharapkan negara-negara di kawasan Asia Tenggara bisa berkompetisi dan bisa menempatkan ASEAN masuk ke dalam pasar terbesar di dunia. (Bobi, 2017). Dengan melakukan sederet kerja sama bukan berarti masalah Ekonomi Indonesia telah selesai. Ada masalah baru yang tercipta dari kerjama ini yaitu perbedaan nilai tukar yang sangat berpengaruh terhadap inflasi.

Pada teori makro ekonomi masalah ekonomi yang selalu dihadapi suatu negara adalah inflasi.Inflasi merupakan kenaikan harga-harga umum yang berlaku dalam suatu perekonomian dari suatu periode ke periode lainnya. Inflasi merupakan salah satu indikator stabilitas perekonomian. Jika tingkat inflasi rendah dan stabil akan menjadi stimulator pertumbuhan ekonomi. (Mankiw dalam Meita dan Wardoyo, 2016) .

Inflasi juga merupakan salah satu indikatorpenting dalam menganalisis perekonomian suatu negara, terutama inflasi berdampak besar terhadap perekonomian agregat meliputi pertumbuhan ekonomi, keseimbangan eksternal, daya saing, tingkat bunga dan distribusi pendapatan (Endri, $2008: 1$ ).

Mengetahui semua ini penting bagi pemerintah untuk melakukan pengendalian inflasi. Pengendalian inflasi sangat penting karena :

1. Memperbanyak distrubusi pendapatan

2. Berkurangnya tabungan domestik

3. Defisitnya neraca perdagangan sehingga memperbanyak utang luar negeri

4. Ketidakstabilan politik (Nugroho, $2012: 5)$

Menurut pemikiran pakar ekonomi muslim ini inflasi akan dapat dihindari jika saja tidak ada perbedaan nilai mata uang dalam suatu negara. Jika emasdan perak dijadikan alat tukar semua negara tentu inflasi dapat dihindari nilai suatu barang sama dan stabil dari waktu kewaktu.

Beberapa penelitan terdahulu membuktikan bahwa perbedaan nilai tukar memberi pengaruh terhadapinflasi disuatu negara. Endri (2008) melakukan penelitan yang berjudul Analisis Faktor-Faktor yang mempengaruhi inflasi di Indonesia, hasil penelitiannya membuktikan bahwa nilai tukar, BI rate, output gap berpengaruh terhadap inflasi.

Selain perbedaan nilai tukar disuatu negara, tingkat suku bunga merupakan salah satu faktor yang dipertimbangkan dapat mempengaruhi inflasi (Santoso, 2010 dalam Nova danWardoyo 2016), Nopirin mendefinisikan suku bunga adalah biaya yang harus dibayar oleh peminjam atas pinjaman yang diterima dan merupakan imbalan bagi pemberi pinjaman atas investasinya.

Kenaikan tingkat suku bunga yang sangat tinggi, pada satu sisi akan efektif untuk mengurangi money suplly, tetapi di sisi lain akan meningkatkan suku bunga kredit untuk sektor riil (Atmadja, 1999 dalam Nova dan Wardoyo 2016). Oleh karena itu, tingkat suku bunga dapat memicu inflasi.

Sistem penetapan bunga sendiri sudah dilarang dalam agama Islam. Salah satu prinsip keuangan syariah adalah pelarangan riba "bebas bunga". Riba sebagai "kelebihan" atas sesuatu akibat penjualan ataupun pinjaman. Riba telah dilarang tanpa adanya perbedaan pendapat di antara para ahli fikih. (Nurhayati dan Washila, $2015: 70$ )

Islam sangat menganjurkan menggunakan sistem bagi hasil bukan bunga dalam aktivitas bisnis. Perbedaan antara bunga dan bagi hasil adalah penetapan pembagian keuntungan yang ditetapkan oleh sistem bunga adalah di awal perjanjian, tanpa mempertimbangkan apakah yang meminjam akan mendapatkan keuntungann atau malah mengalami 
kerugian. Sedangkan dalam sistem bagi hasil jika peminjam mengalami kerugian maka kerugian akan ditanggung bersamasama, begitu juga saat peminjam memperoleh keuntungan maka peminjam akan berbagi juga dengan yang meminjamkan. Dalam konteks ini, Islam melihat keuntungan sebagai buah dari proses kinerja yang nyata dan pengendalian risiko yang baik (Aravik, 2017: 110)

Salah satu Bank yang menggunakan sistem bagi hasil adalah Bank Muamalat Indonesia (BMI). Indonesian pernah mengalami hiper inflasi pada tahun 1998 dimana harga barang mengalami kenaikan hingga $100 \%$ lebih. Banyak perusahaan yang gulung tikar pada masa itu, hal ini dikarenakan perusahaan tidak mampu membayar biaya bunga kredit yang tinggi. Salah satu perusahaan yang tidak mengalami kebangkrutan pada saat itu adalah Bank Muamalat Indonesia (BMI). Ini dikarenakan BMI menetapkan sistem bagi hasil bukan bunga.

Penelitian ini bertujuan untuk menguji pengaruh nilai tukar (kurs) dan suku bunga Bank Indonesia (BI rate). Penelitian ini juga mengungkapkan pandangan para ekonom muslim tentang inflasi, keberadaan uang sebagai alat tukar yang digunakan dan bunga yang ditetapkan. Oleh sebab judul penelitian ini adalah Pengaruh Kurs dan BI rate terhadap inflasi serta pandangan Islam terhadapnya.

\section{Rumusan Masalah}

1. Apakah terdapat pengaruh antara nilai tukar (kurs) terhadap inflasi?

2. Apakah terdapat pengaruh antara BI rate (kurs) terhadap inflasi?

3. Apakah nilai kurs dan BI rate berpengaruh secara bersama-sama terhadap inflasi?

\section{Penelitian Terdahulu}

Banyak penelitian yang membahas tentang inflasi. Endri (2008) melakukan penelitian yang berjudul Analisis FaktorFaktor yang Mempengaruhi Inflasi di
Indonesia (dalam jangka panjang dan jangka pendek). Variabel dependen dalam penelitian ini Inflasi. Sedangkan variabel independennya adalah BI rate, Output gap, dan nilai tukar. Hasil penelitian ini menunjukkan bahwa BI rate, Output gap, dan nilai tukar berpengaruh terhadap inflasi baik dalam jangka panjang maupun pendek. (Endri, 2008: 1)

Asnawi (2009) melakukan penelitian yang berjudul Analisis Faktor-Faktor yang Mempengaruhi Inflasi di Indonesia (dalam jangka panjang dan jangka pendek). Variabel dependen dalam penelitian ini inflasi. Adapun varabel independen dalam penelitian ini antara lain nilaitukar, pendapatan negara, penawaran, penawaran M1, harga minyak dunia. Hasil penelitian ini menunjukkan bahwa nilai tukar, pendapatan negara, penawaran, penawaran M1, harga minyak dunia berpengaruh terhadap inflasi dalam jangka panjang. Namun harga minya dunia tidak berpengaruh terhadap inflasi dalam jangka pendek walapun nilai tukar, pendapatan negara, penawaran, penawaran M1, terhadap inflasi dalam jangka pendek.

Mamik Wahjuanto (2010) melakukan penelitian tentang Beberapa Faktor yang mempengaruhi laju Inflasi di Indonesia. Variabel dependen dalam penelitian ini adalah inflasi. Adapun variaabel independennya Suku bunga BI, Jumlah uang yang beredar, pengeluaran pemerintah, kurs. Hasil penelitian ini menunjukkan bahwa suku bunga BI, Jumlah uang yang beredar, berpengaruh terhadap inflasi sedangkan pengeluaran pemerintah dan kurs tidak berpengaruh terhadap inflasi.

Andrian Surawijaya dan Zulfahmi (2012) melakukan penelitian tentang Pengaruh Faktor-Faktor Ekonomi Terhadap Inflasi Indonesia. Variabel dependen dalam penelitian ini adalah inflasi. Adapun variabel independennya adalah suku bunga, jumlah uang yang beredar, investasi, dan nilai tukar. Hasil penelitian ini menunjukkan bahwa suku bunga, jumlah uang yang beredar, dan 
nilai tukar berpengaruh positif dan signifikan terhadap inflasi. Sedangkan investasi berpengaruh negatif dan signifikan terhadap inflasi.

Kurniawan Saputra (2013) melakukan penelitian yang berjudul Analisis faktorfaktor yang mempengaruhi Inflasi di Indonesia periode 2007-2012. Variabel dependen dalam penelitian ini adalah inflasi. Adapun variabel independennya Jumlah uang yang beredar (JUB), kurs, dan harga beras, dan suku bunga. Hasil penelitian ini menunjukkan bahwa JUB, kurs, dan harga beras berpengaruh positif dan signifikan terhadap inflasi sedangkan suku bunga berpengaruh negatif dan signifikan terhadap inflasi.

Ferayanti, dkk (2014) melakukan penelitian yang berjudul Analisis faktorfaktor yang mempengaruhi Inflasi di Provins Aceh. Variabel dependen dalam penelitian ini adalah inflasi. Adapun variabel independennya adalah kurs dan Peningkatan Perkembangan Produk Domestik Bruto (PDRD). Hasil penelitian ini menunjukkan bahwa kurs dan Peningkatan Perkembangan Produk Domestik Bruto (PDRD) berpengaruh positif dan signifikan terhadap inflas.

Hajunata, dkk (2016) melakukan penelitian berjudul Analisis faktor-faktor yang mempengaruhi Inflasi di Indonesia periode 2000-2014. Variabel dependen dalam penelitian ini adalah inflasi. Adapun variabel independennyaJumlah uang yang beredar (JUB), kurs, minyak dunia, dan BI rate. Hasil penelitian ini menunjukkan bahwa hanya $\mathrm{BI}$ rate yang berpengaruh terhadap inflasi, sedangkan JUB, kurs, minyak dunia, tidak berpengaruh terhadap inflasi.

Meita dan Wardoyo (2016) melakukan penelitian tentang faktor-faktor yang Mempengaruhi Inflasi Indonesia. Variabel dependen dalam penelitian ini adalah inflasi. Adapun variabel independennya JUB, BI rate, kurs dan ekspor bersih. Hasil penelitian ini menunjukkan bahwa JUB, BI rate, kurs berpengaruh terhadap inflasi sedangkan ekspor bersih tidak berpengaruh terhadap inflasi.

\section{Landasan Teori \\ Teori Inflasi Secara Konvensional}

\section{A. Pengertian Dasar}

Inflasi merupakan kenaikan hargaharga umum yang berlaku dalam suatu perekonomian dari suatu periode ke periode lainnya. (Meita dan Wardoyo, 2016 : 1). Menurut Lerner (Gunawan, 1995), inflasi adalah keadaan dimana terjadi kelebihan permintaan (excess demand) terhadap barang dan jasa secara keseluruhan. Sedangkan menurut Sukirno (1998), inflasi merupakan suatu proses kenaikan harga-harga yang berlaku secara umum dalam suatu perekonomian. Sementara itu Mankiw (2000) menyatakan bahwa inflasi merupakan peningkatan dalam seluruh tingkat harga. Hampir semua negara, menjaga inflasi agar tetap rendah dan stabil adalah tugas bank sentral. Tingkat inflasi yang rendah dan stabil, akan tercipta pertumbuhan ekonomi yang diharapkan, perluasan lapangan kerja, dan ketersediaan barang danjasa untuk memenuhi kebutuhan masyarakat. (Sutawijaya dan Zulfahmi, 2012 :86)

\section{B. Jenis - Jenis Inflasi}

Ada berbagai jenis inflasi. Jenis inflasi dalam terbagi menjadi beberapa macam berdasarkan asal, sebabnya dan tingkat keparahannya,

1. Berdasarkan Sebab

a. Demand-pull inflation

Demand pull inflation adalah inflasi yang terjadi karena adanya kenaikan permintaan agregat (agregate demand, AD), sedangkan produksi telah berada pada keadaan kesempatan kerja penuh atau hampir mendekati kesempatan kerja penuh.(Sutawijaya dan Zulfahmi, 2012 : 88)

\section{b. Cost-push Inflation}

Cost-push inflation ditandai dengan kenaikan harga serta turunnya produksi. Keadaan ini timbul dimulai dengan adanya penurunan dalam penawaran agregat 
(Aggregate Supply, AS) sebagai akibat kenaikan biaya produksi. Beberapa contoh penyebab inflasi dari sudut penawaran adalah kenaikan upah pekerja, kenaikan BBM dan kenaikan tarif listrik serta kenaikan tarif angkutan. Kenaikan variabel-bariabel ini akan menyebabkan kenaikan pada biaya produksi. (Sutawijaya dan Zulfahmi, 2012 : 88)

c. Mixed Inflation

Dalam prakteknya, jarang sekali dijumpai inflasi dalam bentuk murni, yaitu inflasi karena tarikan permintaan dan inflasi karena penurunan penawaran yang terjadi sendiri-sendiri. Inflasi yang terjadi di berbagai negara di dunia ini pada umumnya adalah campuran dari kedua macam inflasi di atas, atau apa yang biasa disebut dengan inflasi campuran. (mixed inflation). Inflasi campuran disebabkan karena adanya campuran antara inflasi tarikan permintaan dengan inflasi dorongan biaya. (Sutawijaya dan Zulfahmi, $2012: 89$ )

\section{Berdasarkan Asal}

a. Domestik inflation

Inflasi ini dapat timbul antara lain karena defisit anggaran belanja yang dibiayai dengan pencetakan uang baru ataupun terjadinya kegagalan panen. (Sutawijaya dan Zulfahmi, 2012 : 90)

\section{b. Imported inflation}

Inflasi ini merupakan inflasi yang timbul karena kenaikan harga-harga (inflasi) di luar negeri atau di luar negara tersebut. Dalam hubungan ini pengaruh inflasi dari luar negeri ke dalam negeridapat terjadi melalui kenaikan harga barang-barang impor maupun kenaikan harga barang-barang ekspor. (Sutawijaya dan Zulfahmi, 2012 : 90)

3. Menurut tingkat keparahannya

a. Inflasi ringan

Inflasi yang tingkatannya masih di bawah $10 \%$ setahun

b. Inflasi sedang

Inflasi yang tingkatannya masih diantara $10 \%-30 \%$ setahun c. Inflasi Berat

Inflasi yang tingkatannya masih diantara 30\%-100\% setahun

d. Hiper Inflasi

Inflasi yang tingkat keparahannya berada di atau $100 \%$ setahun.

C. Dampak Inflasi Terhadap Kegiatan Ekonomi Masyarakat

a. Terhadap Konsumen

Inflasi menyebabkan harga-harga barang yang dikonsumsi naik, sementara pendapatan masyarakat tidak mengalami kenaikan. Hal ini berpengaruh pada pola konsumsi masyarakat antara lain :

1. Kuantitas barang yang dikonsumsi berkurang. (Ghofur, 2007 : 135)

2. Peralihan merek dari barang yang dikonsumsi. (Ghofur, 2007 : 136)

b. Terhadap Produksi

Dampak inflasi terhadap produsen terlihat pada keinginan memproduksi yang menjadi menurun, hal ini dikarenakan:

1. Kenaikan harga barang baku

2. Tingkat bunga mengakibatkan perusahaan kesulitan memperluas produksi

3. Munculnya suatu sikap dari produsen spekulatif. (Ghofur, 2007 : 136)

c. Terhadap Distribusi

Dampak inflasi terhadap kegiatan pendistribusian pendapatan masyarakat menjadi terganggi, karena orang berpenghasilan tetap secara rill pendapatannya mengalami kemerosotan. (Ghofur, 2007 : 137)

\section{Pengaruh BI rate terhadap Inflasi}

Sebagaimana yang disebutkan dalam Inflation Targeting Framework bahwa BI Rate merupakan suku bunga acuan Bank Indonesia dan merupakan sinyal (stance) dari kebijakan moneter Bank. Tingkat bunga adalah pembayaran yang dilakukan untuk penggunaan uang. Tingkat bunga adalah jumlah uang yang dibayarkan per unit waktu. Dengan kata lain, masyarakat harus membayar biaya untuk meminjam uang. (Hajunata, dkk, $2016: 4$ ) 
Dengan meningkatnya biaya untuk meminjam uang menyebabkan para pengusaha membayar lebih untuk produksi. Kenaikan biaya produksi tersebut menyebabkan harga barang mengalami peningkatan juga. Jika ini terjadi secara terus-menerus akan menyebabkan terjadinya inflasi. Oleh sebab itu hipotesis kedua dalam penelitian ini adalah

$\mathrm{H} 2$ : BI rate berpengaruh terhadap inflasi

\section{Pengaruh Nilai Tukar terhadap Inflasi}

Nilai tukar Rupiah adalah perbandingan nilai atau harga mata uang Rupiah dengan mata uang lain. Perdagangan antar negara di mana masingmasing negara mempunyai alat tukarnya sendiri mengharuskan adanya angka perbandingan nilai suatu mata uang dengan mata uang lainnya, yang disebut nilai tukar valuta asing atau nilai tukar.

Nilai tukar yang melonjak-lonjak secara drastis tak terkendali akan menyebabkan kesulitan pada dunia usaha dalam merencanakan usahanya terutama bagi mereka yang mendatangkan bahan baku dari luar negeri atau menjual barangnya ke pasar ekspor oleh karena itu pengelolaan nilai mata uang yang relatif stabil menjadi salah satu faktor moneter yang mendukung perekonomian secara makro. (Hajunata, dkk, $2016: 4$ ).

Dengan meningkatnya harga barang baku dari luar, secara otomatis bayaran produksi juga mengalami kenaikan. Kenaikan biaya produksi menyebabkan harga barang mengalami kenaikan, jika keadaan ini terjadi terus-menerus dapat menyebabkan inflasi. Berdasarkan teori di atas maka dapat disimpulkan hipotesis ketiga dalam penelitian ini adalah :

H3 : Nilai tukar bepengaruh terhadap inflasi

Sebelum melakukan uji secara parsial, dalam penelitian ini peneliti akan melakukan uji secara simultan terlebih dahulu. Berdasarkan hipotesis dan kedua teori di atas maka perumusan hipotesis pertama adalah
H1 : BI rate dan nilai tukar berpengaruh secara bersama-sama terhadap inflasi

\section{Teori Inflasi dalam Perspektif Islam}

A. Pengertian Inflasi dalam Perspektif Islam dan Penyebabnya

Inflasi terjadi karena harga-harga secara umum mengalami kenaikan dan berlangsung terus-menerus. Pada saat ini, persediaan barang dan jasa mengalami kelangkaan dan konsumen, karena sangat membutuhkannya mereka (konsumen) harus mengeluarkan lebih banyak uang untuk sejumlah barang dan jasa yang sama. (Al-Maqrizi, 1986: 30 dikutip dalam buku Euis Amalia, 2005: 268 dalam Fadilla, 2017: 2)

Al-Maqrizi mengungkapkan bahwa sejatinya inflasi tidak terjadi karena faktor alam saja melainkan karena faktor kesalahan manusia.

\section{Natural Inflation}

Sesuai dengan namanya, inflasi jenis ini disebabkan berbagai faktor alamiah yang tidak bisa dihindari umat manusia. Menurut Al-Maqrizi ketika suatu bencana alam terjadi, berbagai bahan makanan dan hasil bumi lainnya mengalami penurunan yang sangat drastis dan terjadi kelangkaan.

Di lain pihak, karena sifatnya yang sangat signifikan dalam kehidupan, permintaan terhadap berbagai barang itu mengalami peningkatan. Harga-harga membumbung tinggi jauh melebihi daya beli masyarakat. (Adiwarman Karim, 2014: 425) Al-Maqrizi mengatakan bahwa inflasi ini adalah inflasi yang diakibatkan oleh turunnya Penawaran Agregatif (AS) atau naiknya Permintaan Agregatif (AD). (Fadilla. $2017: 3$ )

Jika memakai perangkat konvensional yaitu persamaan identitas :

$$
\mathrm{MV}=\mathrm{PT}=\mathrm{Y}
$$

Di mana : $\mathrm{M}=$ Jumlah uang beredar

$\mathrm{V}=$ Kecepatan peredaran uang

$\mathrm{P}=$ tingkat harga

$\mathrm{T}=$ Jumlah barang dan jasa $(\mathrm{Q})$

$\mathrm{Y}=$ tingkat pendapatan nasional (GDP) 
Maka Natural Inflation dapat diartikan sebagai :

a. Gangguan terhadap jumlah barang dan jasa yang diproduksi dalam suatu perekonomian (T). Misalnya $\mathrm{T} \downarrow$ sedangkan $\mathrm{M}$ dan $\mathrm{V}$ tetap maka konsekuensinya $\mathrm{P} \uparrow$.

b. Naiknya daya beli masyarakat secara rill. Misalnya nilai ekspor lebih besar dari pada nilai impor, sehingga secara netto terjadi impor uang yang mengakibatkan $\mathrm{M} \downarrow$ sehingga jika $\mathrm{V}$ dan $\mathrm{T}$ tetap maka $\mathrm{P} \uparrow$. (Adiwarman Karim, 2006 : 140 dalam Fadilla, $2017: 2-3$ )

Lebih jauh jika dianalisis dengan persamaan :

$$
\begin{aligned}
& A D=A S \\
& A S=Y \\
& A D=C+I+G+(X-M)
\end{aligned}
$$

Di mana :

$\mathrm{Y}=$ Pendapatan Nasional

$\mathrm{C}=$ Konsumsi

$\mathrm{I}=$ Investasi

$\mathrm{G}=$ Pengeluaran Pemerintah

$(\mathrm{X}-\mathrm{M})=$ net export

Maka Natural Inflation akan dapat dibedakan berdasarkan penyebabnya menjadi dua golongan yaitu sebagai berikut :

a. Akibat uang yang masuk dari luar negeri terlalu banyak, di mana ekspor $(\mathrm{X} \uparrow)$ sedangkan impor $(\mathrm{M} \downarrow)$ sehingga net export nilainya sangat besar, maka mengakibatkan naiknya Permintaan Agregatif (AD $\uparrow)$. Secara Grafis hal ini dapat digrafikan sebagai berikut :

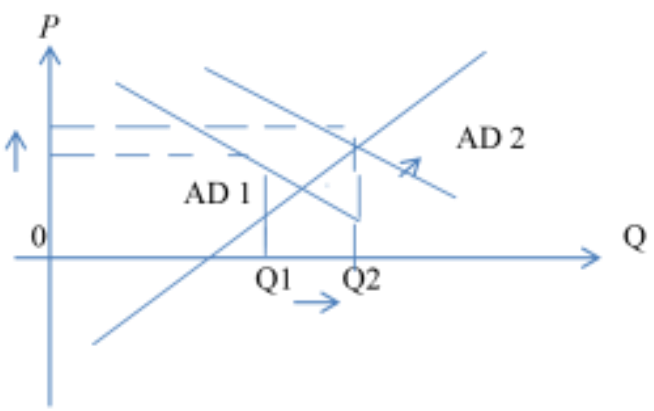

b. Akibat dari turunnya tingkat produksi (AS $\downarrow$ ) karena terjadinya pacekelik, perang, ataupun embargo dan boycott.

2. Human Error Inflation
Selain karena faktor alam inflasi disebabkan oleh kesalahan-kesalahan yang dilakukan oleh manusia. Inflasi ini dikenal dengan istilah human error inflation atau False Inflation. Hal ini juga terdapat dalam Al-Qur'an surat Ar-Rum : 41

"Telah tampaklah kerusakan di darat dan di laut disebebabkan kearena perbuatan manusia, Allah menghendaki agar mereka merasakan sebagian dari (akibat) perbuatan mereka, agar mereka kembali (ke jalan yang benar)".

Menurut Al-Maqrizi inflasi yang terjadi akibat kesalahan manusia antara lain korupsi dan administrasi yang buruk, pajak yang berlebihan dan peningkatan sirkulasi mata uang uang fulus. (Fadilla, $2017: 4$ )

1. Korupsi dan Administrasi yang Buruk

Al-Maqrizi menyatakan bahwa pengangkatan para pejabat pemerintahan yang berdasarkan pemberian suap, dan bukan kapabilitas, akan menempatan orang-orang yang tidak mempunyai kredibilitas pada berbagai jabatan penting dan terhormat, baik di kalangan legislatif, yudikatif, maupun eksekutif.

Mereka rela menggadaikan seluruh harta miliknya sebagai kompensasi untuk meraih jabatan yang diinginkan serta kebutuhan sehari-hari sebagai pejabat. Akibatnya, para pejabat pemerintahan tidak lagi bebas dari intervensi dan intrik para kroni istana. Mereka tidak hanya mungkin disingkirkan setiap saat tetapi justru disita kekayaannya, bahkan dieksekusi.

Kondisi ini, selanjutnya sangat mempengaruhi moral dan efisiensi administrasi sipil dan militer. Ketika berkuasa, para pejabat tersebut mulai menyalahgunakan kekuasaan untuk meraih kepentingan pribadi, baik untuk memenuhi kewajiban finansialnya maupun untuk kemewahan hidup. Mereka berusaha untuk mengumpulkan harta sebanyak-banyaknya dengan menghalalkan segala cara.

Merajalelanya ketidakadilan para pejabat tersebut telah membuat kondisi rakyat semakin memprihatikan, sehingga 
mereka terpaksa meninggalkan kampung halaman dan pekerjaannya. Akibatnya, terjadi penurunan drastis jumlah penduduk dan tenaga kerja serta hasil-hasil produksi yang sangat berimplikasi terhadap penurunan penerimaan pajak dan pendapatan negara. (Fadilla, $2017: 5$ )

Jika kita merujuk pada persamaan $\mathrm{MV}=\mathrm{PT}$, maka korupsi akan mengganggu tingkat harga $(\mathrm{P} \uparrow)$ karena produsen akan menaikan harga jual produksinya untuk menutupi biaya-biaya "siluman" yang telah mereka keluarkan tersebut. Jika merujuk pada persamaan AS-AD maka akan terlihat korupsi dan administrasi pemerintahan yang buruk akan mengakibatkan kontradiksi pada kurva penawaran agregatif (AS $\downarrow)$. (Fadilla, 2017: 5). Hal tersebut tercermin dalam gambar berikut ini.

2. Pajak yang berlebihan

Menurut Al-Maqrizi, akibat dominasi para pejabat bermental korup dalam suatu pemerintahan, pengeluaran negara mengalami peningkatan yangn sangat drastis. Sebagai kompensasinya, mereka menerapkan sistem perpajakan yang menindas rakyat dengan memberlakukan berbagai pajak baru serta menaikan tingkat pajak yang sudah ada. Hal ini sangat mempengaruhi kondisi para petani yang merupakan kelomok mayoritas dalam masyarakat.

Para pemilik tanah yang ingin selalu berada dalam kesenangan akan melimpahkan beban pajak kepada para petani melalui peningkatan biaya sewa tanah. Karena tertarik dengan hasil pajak yang sangat menjanjikan, tekanan para pejabat dan pemilik tanah terhadap para petani menjadi lebih besar dan intensif. Frekuensi berbagai pajak untuk pemeliharaan bendungan dan pekerjaanpekerjaan yang serupa semakin meningkat.

Konsekuensinya, biaya-biaya untuk penggarapan tanah, penaburan benih, pemungutan hasil panen, dan sebagainya meningkat. Dengan kata lain, panen padi yang dihasilkan pada kondisi ini membutuhkan biaya yang lebih besar hingga melebihi jangkauan para petani. Kenaikan harga-harga tersebut, terutama benih padi, hampir mustahil mengalami penurunan karena sebagian besar benih padi yang dimiliki oleh para pejabat yang sangat haus kekayaan.

Akibatnya para petani kehilangan motivasi untuk bekerja dan memproduksi. Mereka lebih memilih meninggalkan tempat tinggal dan pekerjaannya dari pada selalu hidup dalam penderitaan untuk kemudian menjadi pengembara di daerahdaerah pedalaman. Dengan demikian, terjadi penurunan tenaga kerja dan peningkatan lahan tidur yang akan sangat mempengaruhi tingkat hasil produksi padi serta hasil bumi lainnya dan pada akhirnya menimbulkan kelangkaan bahan makanan serta meningkatkan harga-harga. (Fadilla, $2017: 6$ )

3. Peningkatan sirkulasi Mata Uang Fulus

Pada awalnya uang fulus yang mempunyai nilai instrintik jauh lebih kecil dibandingkan dengan nilai nominalnya dicetak sebagai alat transaksi untuk memenuhi kebutuhan hidup sehari-hari yang tidak signifikan. Oleh sebab itu, jumlah mata uang ini hanya sedikit yang terdapat dalam peredaran.

Ketika terjadi defisit anggaran sebagai akibat dari perilaku buruk para pejabat yang menghabiskan uang negara untuk berbagai kepentingan pribadi dan kelompoknya, pemerintah melakukan pencetakan uang fulus secara besarbesaran.

Menurut Al-Maqrizi, kegiatan tersebut semakin meluas pada saat ambisi pemerintah untuk memperoleh keuntungan yang besar dari percetakan mata uang yang tidak membutuhkan biaya produksi tinggi yang tidak terkendali. Sebagai penguasa, mereka mengeluarkan maklumat yang memaksa rakyat untuk menggunakan mata uang itu. Jumlah fulus yang dimiliki masyarakat semakin besar dan sirkulasinya mengalami peningkatan sangat tajam, sehingga fulus menjadi mata uang yang dominan. (Fadilla, $2017: 7$ ) 
$\begin{array}{ccc}\text { Lebih } & \text { jauh, } & \text { Al-Maqrizi } \\ \text { mengemukakan } & \text { bahwa } & \text { kebijakan }\end{array}$ pemerintah tersebut berimplikasi terhadap keberadaan mata uang lainnya. Seiring dengan keuntungan besar yang diperoleh dari pencetakan fulus, pemerintah menghentikan pencetakan perak sebagai mata uang. Bahkan, sebagai salah satu implikasi gaya hidup para penjabat, sejumlah dirham yang dimiliki masyarakat dilebur menjadi perhiasan. Sebagai hasilnya, mata uang dirham mengalami kelangkaan dan menghilang dari peredaran. Sementara itu, mata uang dinar masih terdapat diperedaran meskipun hanya dimiliki oleh segelintir orang. (Fadilla, $2017: 7$ )

Keadaan ini menempatkan fulus sebagai standar nilai bagi sebagian besar barang dan jasa. Kebijakan pencetakan fulus secara besar-besaran, menurut AlMaqrizi, sangat mempengaruhi penurunan nilai mata uang secara drastis. Akibatnya, uang tidak lagi bernilai dan harga-harga membumbung tinggi yang pada gilirannya menimbulkan kelangkaan bahan makanan. (Fadilla, $2017: 7$ ).

\section{B. Akibat Inflasi}

Menurut ekonomi Islam, inflasi berakibat sangat buruk bagi perekonomian karena beberapa hal :

1. Menimbulkan gangguan terhadap fungsi uang, terutama terhadap fungsi tabungan, fungsi pembayaran dimuka dan fungsi unit perhitungan. Akibat dari inflasi itu orang harus melepaskan diri dari uang dan aset keuangan. Inflasi juga mengakibatkan terjadinya inflasi kembali

2. Melemahkan semangat masyarakat untuk menabung

3. Meningkatkan kecenderungan berbelanja, terutama untuk barangbarang non premier dan mewah

4. Mengarahkan investasi kepada hal-hal yang tidak produktif seperti penumpukan kekayaan berupa tanah, bangunan, logam mulia, dan mata uang asing serta mengorbankan investasi produktif seperti pertanian, industri, perdagangan, dan transportasi.

\section{Metode Penelitian}

Penelitian ini menggunakan analisis regresi. Analisis regresi adalah suatu persamaan matematika yang mendefinisikan hubungan antara dua variabel. Tujuan analisis regresi yaitu memprediksi besarnya variabel terdantung (independen) dengan menggunakan data variabel bebas yang sudah diketahui besarnya. (Sunarto, 2017 : 102).

Adapun persamaan regresi dalam penelitian ini adalah :

$$
\begin{aligned}
& \mathrm{Y}=\mathrm{a}+\mathrm{b}_{1} \mathrm{X}_{1}+\mathrm{b}_{2} \mathrm{X}_{2} \\
& \text { Ket : } \\
& \mathrm{Y} \text { : inflasi } \\
& \mathrm{a} \text { : konstanta } \\
& \mathrm{X} 1 \text { : BI rate } \\
& \mathrm{X} 2 \text { : kurs }
\end{aligned}
$$

\section{HASIL DAN PEMBAHASAN Analisis Deskriptif}

Penelitian ini meliputi tiga (3) variabel yang terdiri dari satu (1) variabel dependen dan dua (2) variabel independen. Variabel dependen dalam penelitian ini adalah inflasi. Sedangkan variabel independennya adalah BI rate dan kurs. Unit analisis dalam penelitian ini 71 Sampel size. Adapun hasil statistik deskriptif terhadap variabel penelitian tampal pada Tabel 1.1 di bawah ini

Tabel 1.1.

Deskriptif Statistic

\begin{tabular}{|l|l|l|l|l|l|}
\hline $\begin{array}{c}\text { Nama } \\
\text { Variabel }\end{array}$ & $\mathrm{N}$ & Minimum & Maximum & Mean & $\begin{array}{c}\text { Standar } \\
\text { Deviasi }\end{array}$ \\
\hline Inflasi & 71 & 0,03 & 0,09 & 0,0530 & 0,01722 \\
\hline BI rate & 71 & 0,04 & 0,08 & 0,0629 & 0,01156 \\
\hline Kurs & 71 & 8992 & 14488 & 1.1981 & 1661.721 \\
\hline
\end{tabular}

Sumber : hasil olah data sekunder

Pada Tabel 1.1. di atas tampakbahwa variabel inflasi memiliki nilai minimum 0,03 hal ini menunjukkan bahwa tingkat inflasi yang paling kecil pada periode penelitian ini adalah $0,03(3 \%)$. Nilai maximum 0,09 yang berarti bahwa tingkat inflasi tertinggi adalah $9 \%$. Nilai mean 0,053 menunjukkan bahwa rata-rata 
tingkat inflasi adalah 5,3\%. dan standar deviasi bernilai 0,01722 nilai ini lebih kecil dari pada nilai rata-rata berarti data ini sudah terdistribusi normal

Pada Tabel 1.1. di atas tampakbahwa variabel $\mathrm{BI}$ rate memiliki nilai minimum 0,04, nilai maximum, mean 0,0629 dan standar deviasi 0,011. Hal ini menunjukkan bahwa tingkat BI rate yang terendah pada periode penelitian adalah $4 \%$, tertinggi $8 \%$. Adapun rata-rata BI rate pada penelitian ini adalah $6,29 \%$. Sedangkan standar deviasi bernilai 0,01156, nilai ini lebih kecil dari pada nilai rata-rata penelitian hal ini menunjukkan bahwa data BI rate yang di pakai dalam penelitian ini sudah terdistribusi normal.

Pada Tabel 1.1. di atas tampak bahwa variabel nilai tukar (kurs) memiliki nilai minimum 8992 dan maximum14488, ini berarti nilai tukar terendah pada tahun 2012 sampai tahun 2017 adalah Rp. 8992 dan terringgi adalah Rp. 14488. Adapun nilai rata-rata adalah 1.1981 yang berarti bahwa nilai tukar rata-rata pada penelitian ini adalah Rp. 11.981. Standar deviasi pada periode penelitian 1661.721 artinya variabel nilai tukar belum terdistribusi normal.

\section{Uji Normalitas}

Setelah dilakukan uji statistik pada semua variabel di atas yang memiliki jumlah populasi $71(\mathrm{~N}=71)$, untuk variabel nilai tukar (kurs) tidak memenuhi asumsi normalitas. Oleh sebab itu peneliti mentransformasikan variabel kurs menjadi bentuk logaritma natural (Ln). Selain itu ada beberapa data yang dihilangkan karena jika data tersebut dimasukan membuat penelitian ini menjadi bias. Data seperti ini disebut dengan data outlier.

Setelah menghilangkan beberapa yang outlier, akhirnya data yang digunakan oleh peneliti menjadi42 (empat puluh dua). Peneliti menggunakan Uji one-sample kolmogorov-smirnov testuntuk menguji apakah data yang dipakai dalam penelitian ini sudah terdistribusi normal atau belum.
Jika nilai Asymp.Sig (2-tailed) lebih besar (>) 0,05, hal ini berarti bahwa data yang digunakan sudah terdistribusi normal. Sebaliknya jika nilai Asymp.Sig (2-tailed) lebih $\operatorname{kecil}(<)$ 0,05 menunjukkan bahwa data yang digunakan dalam penelitian ini belum terdistribusi normal. Pada Tabel 1.2. di bawah ini dapat dilihat nilai dari hasil uji one-sample kolmogorov-smirnov test.

Tabel 1.2.

Hasil Uji one-sample kolmogorovsmirnov test

\begin{tabular}{|c|c|c|c|}
\hline Variabel & $\mathrm{N}$ & $\begin{array}{c}\text { Nilai } \\
\text { Asymp.Sig } \\
\text { (2-tailed) }\end{array}$ & Kesimpulan \\
\hline Inlasi & 42 & 0,158 & $\begin{array}{c}\text { Data } \\
\text { normal }\end{array}$ \\
\hline BI rate & 42 & 0,062 & $\begin{array}{c}\text { Data } \\
\text { normal }\end{array}$ \\
\hline Kurs & 42 & 0,135 & $\begin{array}{c}\text { Data } \\
\text { normal }\end{array}$ \\
\hline
\end{tabular}

Sumber data sekunder yang diolah

Pada tabel 1.2 terlihat bahwa nilai Asymp.Sig (2-tailed) untuk variabel inflasi 0,158 , nilai ini $>$ dari pada 0,05 . Jadi dapat disimpulkan bahwa untuk variabel inflasi yang merupakan variabel dependen dalam penelitian ini terdistribusi normal. Begitupun juga dengan kedua variabel yang lain yaitu BI rate dan kurs. BI rate memiliki nilai Asymp.Sig (2-tailed) 0,062 dan kurs 0,132. Nilai keduanya $>0,05$. Hal ini berarti baik $\mathrm{BI}$ rate maupun kurs terdistribusi normal.

\section{Uji Multikolinieritas}

Uji asumsi klasik kedua peneliti lakukan adalah uji multikolinieritas. Uji ini dilakukan untuk mendeteksi ada atau tidaknya multikolinieritas pada model regeresi yang digunakan. Terjadinya multikolinieritas menyebabkan penelitian menjadi bias. Agar penelitian tidak bias nilai tolerance harus diatas $(>)$ dari 0,10 dan nilai VIF harus dibawah $(<) \quad 10$. Adapun nilai tolerance dan VIF dapat dilihat dari tabel di bawah ini. 
Tabel 1.3

Tabel Multikolinieritas

\begin{tabular}{|l|l|l|l|l|}
\hline \multirow{2}{*}{ Persamaan } & \multirow{2}{*}{ Variabel } & \multicolumn{2}{|l|}{$\begin{array}{l}\text { Collinierity } \\
\text { Statistics }\end{array}$} & \multirow{2}{*}{ Kesimpulan } \\
\cline { 3 - 4 } & & Tolerance & VIF & \\
\hline \multirow{3}{*}{ Inflasi } & BI rate & 0,989 & 1,011 & $\begin{array}{l}\text { Non-multi } \\
\text { koliniertitas }\end{array}$ \\
\cline { 2 - 5 } & Ln_kurs & 0,989 & 1,011 & $\begin{array}{l}\text { Non-multi } \\
\text { koliniertitas }\end{array}$ \\
\hline
\end{tabular}

Sumber: data sekunder yang diolah

Uji multikolinieritas di atas menunjukkan bahwa untuk semua variabel independen, diperoleh nilai tolerance berada di atas0,1dan nilaiVIF di bawah 10. Hal ini menunjukkan bahwa tidak terjadi multikolinieritas pada model regresi yang digunakan.

\section{Uji Heterokedastisitas}

Uji heterokedastisitas bertujuan menguji apakah dalam model regresi terjadi ketidaksamaan variance dari residual satu pengamatan ke pengamatan yang lain.Jika variance dari residual satu pangamatan ke pengamatan lain tetap maka disebut dengan homoskedastisitas dan jika berbeda disebut dengan heterokedastisitas.

Model regresi yang baik adalah yang homoskedastisitas atau tidak terjadi heterokedastisitas.(Ghozali, 2009: 125). Dalam penelitian ini pengujian heterokedastisitas dengan melihat grafik plot antara prediksi variabel terikat (dependen) yaitu ZPRED dengan residualnya SREID. Gambar 1.1. dibawah ini merupakan hasil ujinya
Gambar 1.1

Scatterplot

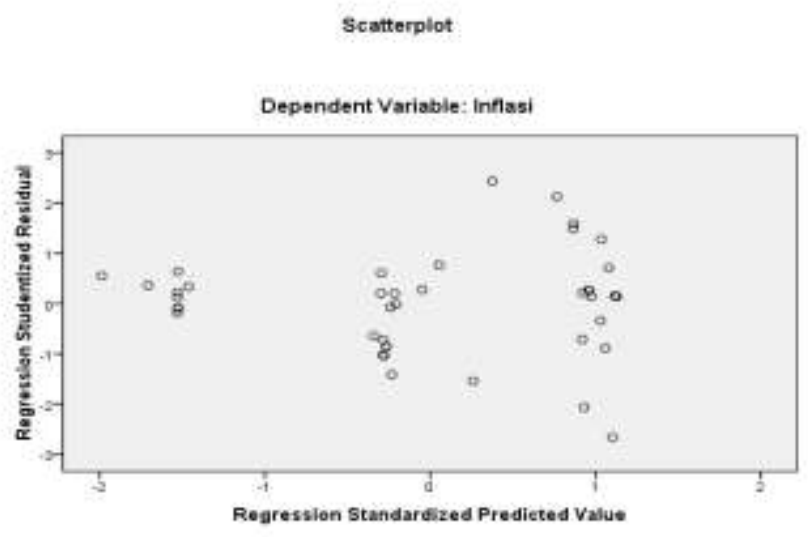

Pada Gambar 1.1. di atas terlihat bahwa titik-titik menyebar secara acak serta tersebar baik diatas angka 0 pada sumbu $\mathrm{Y}$ ataupun dibawah sumbu 0 pada sumbu Y. Hal ini membuktikan bahwa pada model regresi yang digunakan tidak terjadi heterikedastisitas,sehingga layak dipakai untuk menguji variabel independen terhadap variabel dependen.

\section{Uji Pengaruh Simultan ( F test)}

Uji pengaruh simultan digunakan untuk mengetahui apakah variabel independen secara bersama-sama atau simultan mempengaruhi variabel dependen. (Ghazali, 2009 :163) Uji ini dapat dilihat pada nilai sig. Pada tabel Anova. Kriteria pengujiaannya ialah jika nilai sig< 0,05 maka dapat disimpulkan bahwa $\mathrm{HO}$ ditolak hal ini berati terdapat pengaruh variabel independen terhadap variabel dependen secara bersama-sama.

Sebaliknya jika nilai sig> 0,05 maka dapat disimpulkan bahwa $\mathrm{HO}$ diterima hal ini berati tidak terdapat pengaruh variabel independen terhadap variabel dependen secara bersama-sama. Pada penelitian ini, peneliti akan menguji pangaruh BI rate dan kurs terhadap inflasi. Hasil Uji F tersebut dapat dilihat pada Tabel 1.4. di bawah ini 
Tabel 1.4. Hasil Uji F terhadap inflasi

\begin{tabular}{|l|l|l|l|}
\hline Sampel & F & Signifikansi & Kesimpulan \\
\hline 41 & 33,976 & 0,000 & $\begin{array}{l}\text { Model } \\
\text { regresi dapat } \\
\text { digunakan }\end{array}$ \\
\hline
\end{tabular}

Sumber : data sekunder yang diolah

Pada Tabel 1.4. di atas dapat dilihat bahwa hasil signifikansi uji $\mathrm{F}$ untuk inflasi adlah 0,000. Nilai 0,0000 di bawah 0,05, hal ini berarti bahwa terdapat pengaruh simultan antara BI rate dan kurs terhadap inflasi.

\section{Uji Koefisien Determinasi}

Koefisien determinasi digunakan untuk menguji goodness-fit dari model regresi. (Ghazali, 2009 :163)Besarnya nilai adjusted $\mathrm{R}^{2}$ sebesar 0,635 yang berarti variabilitas variabel inflasi yang dapat dijelaskan oleh BI rate dan kurs adalah $63,5 \%$ sedangkan sisanya yaitu $36,5 \%$ dijelaskan oleh variabel lain yang tidak diujikan dalam penelitian ini.

Tabel 1.5 Hasil Uji determinasi

\begin{tabular}{|l|l|}
\hline Variabel dependen & R Square \\
\hline Inflasi & 0,635 \\
\hline
\end{tabular}

Sumber : data sekunder yang diolah

\section{Uji Parsial (t test)}

Uji parsial digunakan untuk mengetahui pengaruh masing-masing variabel independen terhadap variabel dependen. Dari ke dua variabel independen yaitu BI rate dan Ln_kurs hanya satu variabel independen yaitu BI rate yang berpengaruh terhadap inflasi sedangkan Ln_kurs tidak berpengaruh terhadap inflasi. Hasil uji $\mathrm{t}$ terlihat dari tabel 1.6 di bawah ini.
Tabel 1.6

Hasil Pengujian terhadap Inflasi

\begin{tabular}{|c|c|c|c|c|c|}
\hline \multirow{2}{*}{$\begin{array}{l}\text { Persa- } \\
\text { maan }\end{array}$} & \multirow[t]{2}{*}{ Variabel } & \multicolumn{3}{|c|}{ Collinierity Statistics } & \multirow[t]{2}{*}{ Kesimpulan } \\
\hline & & standar & $\mathrm{t}$ & sig & \\
\hline \multirow[t]{2}{*}{ Inflasi } & $\mathrm{BI}$ rate & 0,800 & 8.999 & 0,000 & signifikan \\
\hline & Ln_kurs & $-0,132$ & $-1,361$ & 0,181 & $\begin{array}{l}\text { Tidak } \\
\text { Signafikan }\end{array}$ \\
\hline
\end{tabular}

Sumber : data sekunder yang diolah

\section{Pengaruh BI rate terhadap Inflasi}

Telah diungkapkan pada hipotesis kedua (H2) dalam penelitian ini yaitu BI rate berpengaruh terhadap inflasi. Pada tabel 1.6 terlihat bahwa nilai signifikansi t adalah 0,000 pada 8,999 yang berati bahwa BI rate berpengaruh positif dan signifikan terhadap inflasi.

Jika tingkat suku bunga naik maka tingkat inflasi juga mengalami kenaikan sebaliknya jika suku bunga turun maka tingkat inflasi juga mengalami penurunan. Hasil penelitian ini mendukung hasil penelitian yang dilakukan oleh Endri (2008), Andrian sutawijaya dan Zulfahmi (2012). Hal ini membuktikan hipotesis pertama dan kedua dalam penelitian ini diterima.

Penelitian ini membuktikan sekali lagi bahwa penetapan suku bunga akan sangat berpengaruh terhadap perekonomian suatu negara dan yang paling kuat terlihat adalah inflasi dalam negara itu sendiri. Dampak dari penetapan suku bunga yang paling terlihat adalah inflasi yang terjadi pada Indonesia pada tahun 1999. Banyak perusahaan yang gulung tikar karena tidak mampu membayar bunga pinjaman yang tinggi.

Beberapa waktu tahun terkahir ini sudah banyak lembaga keuangan baik Bank maupun non-bank yang berlombalomba untuk membuka usaha keuangan yang berbasis bagi hasil dan bukan bunga. Ini dilakukan agar kita tidak terkena dampak dari penetapan sistem bunga yang sangat merugikan bagi kita selaku peminjam dan agar terciptanya keadilan antara peminjam dan yang meminjamkan uang. Untung dan rugi ditanggung bersama-sama. 
Sebagai umat muslim sudah seharusnya ikut mensukseskan lembagalembaga keuangan seperti ini minimal dengan cara menjadi nasabah di Bankbank syariah. Hal ini setidaknya ikut serta mendukung perubahan keuangan di dalam negara ini agar terbebas dari riba. Apalagi bank-bank Syariah juga mulai booming dan banyak didirikan oleh negara-negara Eropa dan Amerika.

\section{Pengaruh Nilai tukar (kurs) terhadap Inflasi}

Hipotesis ketiga dalam penelitian ini adalah nilai kurs berpengaruh terhadap inflasi. Pada Tabel 1.6 menunjukkan bahwa nilai t kurs adalah -1,361 dan nilai signifikansinya adalah 0,181 berarti Ho diterima. Hal ini membuktikan bahwa bahwa kurs tidak berpengaruh terhadap inflasi. Sehingga hipotesis ketiga dalam penelitian ini ditolak

Hasil penelitian ini mendukung hasil penelitian yang dilakukan oleh Wahjuanto (2012), Nova dan Wardoyo (2012), dan Hajunata, dkk (2016). Hasil penelitian ini menolak hasil penelitian yang dilakukan oleh Kurniawan Saputra (2013), Feryanti, dkk (2014).

Ada beberapa sebab mengapa pada tahun 2012-2017 nilai tukar tidak berpengaruh terhadap inflasi yang terjadi di Indonesia. Peningkatan nilai UMR (upah minimum regional) menjadi salah satu penyebabnya. Jumlah UMR di bebeapa kota besar Indonesia mengalami kenaikan sepanjang tahun 2012-2017. Tabel 1.7.di bawah ini menunjukkan jumlah UMR di kota-kota besar di Indonesia.

Tabel 1.7

Perkembangan UMR di kota-kota besar Indonesia

\begin{tabular}{|l|r|l|l|l|l|}
\hline Kota & \multicolumn{1}{|c|}{2012} & 2013 & 2014 & 2015 & 2016 \\
\hline Subar & 1.150 .000 & 1.350 .000 & 1.490 .000 & 1.615 .000 & 1.800 .725 \\
\hline Jambi & 1.142 .500 & 1.300 .000$. & 1.502 .300 & 1.710 .000 & 1.906 .650 \\
\hline Sumsel & 1.192 .220 & 1.630 .000 & 1.825 .000 & 1.975 .346 & 2.206 .000 \\
\hline Lampung & 975.000 & 1.150 .000$. & 1.399 .037 & 1.581 .000 & 1.763 .000 \\
\hline Jakarta & 1.529 .150 & 2.200 .000$. & 2.441 .000 & 2.700 .000 & 3.100 .000$. \\
\hline Riau & 1.050 .000 & 1.365 .000 & 1.665 .000 & 1.954 .000 & 2.178 .710 \\
\hline Kalteng & 1.327 .459 & 1.553 .127 & 1.723 .730 & 1.896 .367 & 2.057 .558 \\
\hline
\end{tabular}

Sumber : badan pusat statistik
Walaupun harga barang-barang cenderung meningkat namun dengan memiliki keuangan yang cukup, masyarakat Indonesia tidak terlalu merasakan dampaknya karena memiliki uang yang mereka miliki cukup untuk membiayai kelebihan kebutuhan yang diperlukan. Hal ini menyebabkan nilai tukar tidak terlalu berdampak pada inflasi, karena masyarakat punya uang yang lebih untuk menutupinya.

Berikut ini hasil pengujian korelasi antara inflasi di Indonesia dengan UMR (Upah Minimum Regional) di kota Palembang.

Tabel 1.8

Hasil Uji Korelasi Selisi Inflasi dan UMR kota Palembang

\begin{tabular}{|l|l|l|l|l|l|}
\hline $\mathrm{N}$ & $\mathrm{X}$ & $\mathrm{Y}$ & $\mathrm{X}^{2}$ & $\mathrm{X} . \mathrm{Y}$ & $\mathrm{Y}^{2}$ \\
\hline 1 & 437.780 & 0,023 & 0,000529 & $10.068,94$ & 1.916 .513 .284 .000 \\
\hline 2 & 195.000 & $-0,006$ & 0,000036 & -1170 & 380.250 .000 .000$. \\
\hline 3 & 143.346 & $-0,025$ & 0,000625 & $-3583,65$ & 205.540 .075 .720 \\
\hline 4 & 234.645 & $-0,004$ & 0,000016 & $-938,61$ & 506.624 .997 .000 \\
\hline$\sum$ & 1.010 .780 & $-0,012$ & 0,001206 & $4.376,68$ & 2.829 .928 .367 .000 \\
\hline
\end{tabular}

$$
\begin{aligned}
& r=\frac{n \sum X y-\sum X \sum Y}{\sqrt{n} \sum X 2-\left(\sum X\right) \sqrt{n} \sum Y 2-\left(\sum Y\right) 2} \\
& r=\frac{4 x 4376,86-1.010 .780 x(-0,012)}{\sqrt{0,0684397} x \sqrt{110299263}} \\
& r=\frac{5377,36}{33321153,39} \\
& r=0,000001312
\end{aligned}
$$

Ket :

$\mathrm{r}$ : korelasi

$\mathrm{X}$ : selisih UMR kota Palembang

$\mathrm{Y}$ : selisih inflasi

$\mathrm{n}$ : waktu

$\sum:$ jumlah

Hasil perhitungan korelasi di atas menunjukkan bahwa korelasi mendekati +1 . Ini berarti bahwa setiap kenaikan skor/ nilai pada variabel $\mathrm{X}$ akan diikuti dengan skor/nilai variabel Y. Sebaliknya,jika variabel $\mathrm{X}$ mengalami penurunan, maka akan diikuti dengan penurunan variabel $\mathrm{Y}$. (Irianto, $2015:$ 141).

Hasil perhitungan regresi menunjukkan angka 0,0000134, nilai ini mendekati +1 . Hal ini berarti antara inflasi dan UMR kota Palembang berkorelasi positif. Jika inflasi mengalami kenaikan 
maka pemerintah menaikan UMR, sebaliknya jika inflasi mengalami penurunan maka UMR juga akan berkurang untuk ditingkatkan. Hal inilah yang menyebabkan nilai tukar tidak terlalu berdampak pada inflasi, karena pemerintah telah menaikan penghasilan masyarakat untuk mengatasinya.

\section{Kesimpulan}

Inflasi merupakan masalah dalam sebuah negara terutama negara berkembang, salah satunya negara kita Indonesia. Banyak hal yang menyebabkan inflasi. Dalam penelitian ini ada dua variabel yang diuji yaitu BI rate dan nilai tukar. Hasil penelitian ini menunjukkan bahwa hanya Birate yang berpengaruh terhadap inflasi sedangkan nilai tukar tidak berpengaruh.

Tidak berpengaruhnya nilai tukar terhadap inflasi dikarenakan pemerintah menaikan tingkat UMR di beberapa kota besar di Indonesia. Setelah dilakukan uji korelasi hasilnya membuktikan bahwa pemerintah melakukan sejumlah kebijakan juga untuk mengantisipaso dampal dari kebaikan inflasi di Indonesia.

\section{DAFTAR PUSTAKA}

Aravik, Havis. 2017. Sejarah Pemikiran Ekonomi Islam Kontemporer. Jakarta: Kencana.

Asnawi. 2009. "Analisis Faktor-Faktor yang Mempengaruhi Inflasi di Indonesia (dalam jangka panjang dan jangka pendek)". Mantekh.Vol.1.No.1.

Irianto, Agus. 2015. Statistik; Konsep Dasar, Aplikasi dan Pengembangannya. Padang: Kencana.

Endri. 2008. “Analisis Faktor-Faktor yang Mempengaruhi Inflasi di Indonesia (dalam jangka panjang dan jangka pendek)". Jurnal ekonomi pembangunan (kajian ekonomi negara berkembang).Vol.13.No.1.

Fadilla, 2017. Islamic Banking. Jurnal Pemikiran dan Pengembangan Perbankan Syariah. Vol. 2.No. 2.

Ferayanti, Raja Masbar, Sofyan Syahnur. 2014. "Analisis Faktor-Faktor yang Mempengaruhi Inflasi di Provins Aceh." Jurnal Ilmu Ekonomi Pascasarjana Universitas Syiah Kuala. Vol.2 No. 2.

Ghazali, Imam. 2009. Aplikasi Analisis Multivariate Dengan Program SPSS. Badan Penerbit Universitas Diponogoro.

Ghofur, Muhamad, 2007. Pengantar Ekonomi Moneter (Tinjauan Ekonomi Konvensional dan Islam), Yogyakarta : Biruni Press.

Hajunata, Y.T.Kalalo, Tri Oldy Rotunsulu, Mauna Th. B. Maramis. 2016. "Analisis faktor-faktor yang mempengaruhi Inflasi di Indonesia periode 2000-2014". Jurnal Berkala Ilmiah Efisiensi. Vol.16. No.1.

Saputra, Kurniawan. 2013. "Analisis Faktor-Faktor yang Mempengaruhi Inflasi di Indonesia periode 20072012”. Skripsi. Universitas Dipenogoro.

Wahjuanto, Mamik. 2010. "Beberapa Faktor yang mempengaruhi laju Inflasi di Indonesia". Sripsi. Universitas Pembangunan Nasional "Veteran"

Nova, Meita Yanti Panjaitan dan Wardoyo. 2016. "Faktor-Faktor yang Mempengaruhi Inflasi Indonesia". Jurnal Ekonomi Bisnis Vol.21 No. 1. 
Sunarto, Endang. 2017. Statistik Untuk Ekonomi dan Bisnis Islam. Bengkulu: Pustaka Pelajar. Bengkulu. IAIN Bengkulu Pers.

Sutawijaya, Adrian dan Zulfahmi. 2012. "Pengaruh Faktor-Faktor Ekonomi
Terhadap Inflasi Indonesia”. Jurnal Organisasi dan Manajemen. Vol. 8. No. 2.

https://www.bps.go.id/linkTableDinamis/v iew/id/917, di akses tanggal 25 Januari 2018 